\title{
Mortality rates and neonatal intensive care for very small babies
}

\author{
GODFREY J A WALKER AND HAZEL SIMPSON \\ Department of Community Health, London School of Hygiene and Tropical Medicine
}

SUMMARY Mortality rates of very small babies (those weighing $1500 \mathrm{~g}$ or less) born to mothers normally resident in the 11 health districts of the London portion of the North-east Thames Health Region in 1971-73 and 1975-77 were compared with admission rates to neonatal intensive care units in 1972 and 1976 in the region. There was no significant correlation between mortality and admission rates for babies weighing $1000 \mathrm{~g}$ or less during either period. For babies born weighing between 1001 and $1500 \mathrm{~g}$ this was also so in 1972. In 1976 however, mortality rates were significantly correlated negatively at 24 hours but not at 28 days with admission rates to neonatal intensive care.

There has been much discussion about the importance of neonatal intensive care ${ }^{1-8}$ on the survival of very low birthweight babies. Reynolds ${ }^{10}$ has repeatedly maintained that since about 1965 , when intensive care became more universally available, the proportion of small babies surviving has increased. Others argue that although there has been an overall improvement in survival rates, ${ }^{11}$ the contribution that sophisticated neonatal care makes is doubtful. ${ }^{1-356}$

A policy of regional organisation of intensive care services for very small and sick babies has developed in this country during the last decade. ${ }^{12}$ In recent years there have been pronounced changes in the number of very small babies admitted and an increase in their lengths of stay. ${ }^{13}$ The high level of technology and skills devoted to neonatal intensive care has resulted in the provision of one or two centres for each health region, each centre serving a population of between 2 and 4 million. A disadvantage of such a concentration of services is that babies born in inaccessible parts of a region may make less use of the services.

To establish whether there are local disparities in the use of neonatal care services, and if there are differences in overall mortality rates for very small babies born in districts with varying utilisation rates of neonatal intensive care, admissions to such care in one region-the North-east Thames Health Regionhave been reviewed.

\section{Methods}

There are two neonatal intensive care units in the region-one at The London Hospital (Whitechapel) with 12 cots, and the other at University College Hospital (UCH) with 18 cots. Details of each baby's birthweight and the mother's home address were obtained for every baby admitted to the units during 1972 and 1976 from the ward record books. Details of age at admission could not be obtained as age was not consistently recorded at both units. Babies born to mothers normally resident outside the region were excluded.

For all districts the number of babies of very low birthweight, and the number of deaths in the first 24 hours and within 28 days were obtained for the years 1971-73 and 1975-77 from community health returns (LHS 27/1). Mortality rates were analysed separately for babies weighing $1000 \mathrm{~g}$ and less, and for babies weighing 1001-1500 g at birth.

A questionnaire was sent to all consultants at each of the 19 special care baby units to find out which neonatal intensive care units were being used by paediatricians and whether there had been any changes in practice between 1972 and 1976.

\section{Results}

Answers to the questionnaire were received from 17 of the special care baby units in the region. These showed that most paediatricians at special care baby units referred babies to either UCH (9) or The London (5) for neonatal intensive care. Three of these 14 said they only occasionally transferred babies as they considered they themselves were able to provide most forms of intensive care. One paediatrician said he never referred babies elsewhere. 


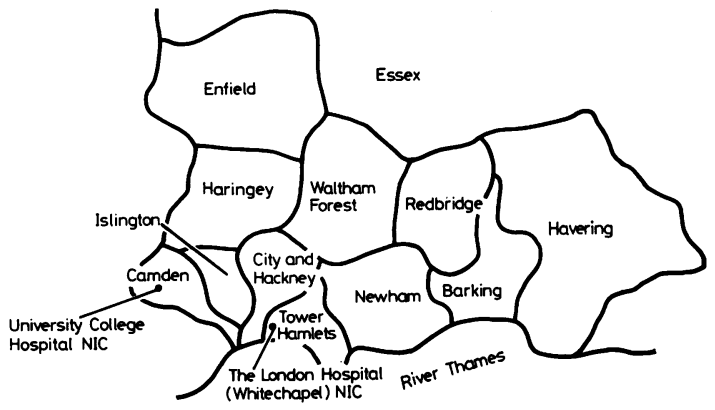

Fig. 1 The Greater London part of the North-east Thames Health Region and location of neonatal intensive care (NIC) units.

Table 1 Survival rates of babies weighing $1500 \mathrm{~g}$ or less admitted to neonatal intensive care units in the North-east Thames Health Region 1972 and 1976*

\begin{tabular}{|c|c|c|c|c|c|c|c|c|c|c|c|}
\hline \multicolumn{12}{|c|}{ Neonatal intensive care unit } \\
\hline \multicolumn{4}{|c|}{$\begin{array}{l}\text { The London } \\
\text { Hospital }\end{array}$} & \multicolumn{3}{|c|}{$\begin{array}{l}\text { University } \\
\text { College } \\
\text { Hospital }\end{array}$} & & \multicolumn{4}{|c|}{ Both hospitals } \\
\hline \multicolumn{2}{|l|}{1972} & \multicolumn{2}{|l|}{1976} & \multicolumn{2}{|l|}{1972} & \multicolumn{2}{|l|}{1976} & \multicolumn{2}{|l|}{1972} & \multicolumn{2}{|l|}{1976} \\
\hline$P$ & $\%$ & $P$ & $\%$ & $P$ & $\%$ & $P$ & $\%$ & $P$ & $\%$ & $P$ & $\%$ \\
\hline $7 / 18$ & 39 & $38 / 82$ & 46 & $16 / 35$ & 46 & $66 / 102$ & 65 & $23 / 53$ & 43 & $104 / 194$ & 54 \\
\hline
\end{tabular}

$\mathbf{P}=$ number of survivors/total admissions.

*Developed from data extracted from neonatal intensive care admission books at the two hospitals.
Consultants at two hospitals in Essex said they normally approached the unit at Addenbrooke's Hospital, Cambridge. Because of this, it was decided to limit the analysis of utilisation to the Greater London part of the region (Fig. 1). Admission rates were calculated for babies weighing $1000 \mathrm{~g}$ and less, and for those weighing 1001-1500 $\mathrm{g}$, for these 11 districts.

For babies transferred from special care baby units in these districts, it was stated that when referrals were made it was as a first or second choice to the two regional units. There was said to have been no change in the units approached in 1976 compared with 1972 , but it was felt that it had become more difficult to get a baby admitted.

Survival rates of very small babies (those weighing $1500 \mathrm{~g}$ or less) admitted to the two units have increased (Table 1). At UCH this improvement is statistically significant $(0.05>P>0.01)$. However these changes might be partly due to the admission of a greater number of less severely ill babies.

When babies born to mothers normally resident in the 11 districts of the north-eastern part of Greater London are considered, the percentage of babies of very low birthweight admitted to intensive care has increased strikingly, from $9 \%$ in 1972 to $57 \%$ in 1976 for babies of $1000 \mathrm{~g}$ or less at birth, and from 14 to $55 \%$ for babies weighing 1001-1500 g (Tables 2 and 3 ). The birthweights of babies admitted to intensive care from these 11 districts in the region during 1972

Table 2 Live births $\dagger$, deaths within 24 hours $\dagger$ and 28 days $\dagger$, and admissions + to neonatal intensive care for babies weighing $1000 \mathrm{~g}$ or less by health district, Greater London part of North-east Thames Health Region

\begin{tabular}{|c|c|c|c|c|c|c|c|c|c|c|c|c|c|c|}
\hline \multirow[t]{4}{*}{ Health district } & \multicolumn{5}{|c|}{$1971-73$} & \multirow{2}{*}{\multicolumn{2}{|c|}{$\begin{array}{l}1972 \\
\begin{array}{l}\text { Admitted for } \\
\text { intensive care }\end{array}\end{array}$}} & \multicolumn{5}{|c|}{$1975-77$} & \multirow{2}{*}{\multicolumn{2}{|c|}{$\begin{array}{l}1976 \\
\begin{array}{l}\text { Admitted for } \\
\text { intensive care }\end{array}\end{array}$}} \\
\hline & \multirow[t]{3}{*}{$\begin{array}{l}\text { Live } \\
\text { births }\end{array}$} & \multicolumn{4}{|c|}{ Deaths within } & & & \multirow[t]{3}{*}{$\begin{array}{l}\text { Live } \\
\text { births }\end{array}$} & \multicolumn{4}{|c|}{ Deaths within } & & \\
\hline & & \multicolumn{2}{|c|}{24 hours } & \multicolumn{2}{|c|}{28 days } & \multirow[b]{2}{*}{ No } & \multirow[b]{2}{*}{$\%$} & & \multicolumn{2}{|c|}{24 hours } & \multicolumn{2}{|c|}{28 days } & \multirow[b]{2}{*}{ No } & \multirow[b]{2}{*}{$\%$} \\
\hline & & No & $\%$ & No & $\%$ & & & & No & $\%$ & No & $\%$ & & \\
\hline Barking & 13 & 10 & $76 \cdot 9$ & 12 & $92 \cdot 3$ & $0 / 5$ & $(0)$ & 12 & 7 & $58 \cdot 3$ & 12 & 100 & $0 / 6$ & (0) \\
\hline Camden & 21 & 11 & $52 \cdot 4$ & 18 & $85 \cdot 7$ & $1 / 7$ & $(14 \cdot 3)$ & 19 & 4 & $21 \cdot 1^{* * *}$ & 17 & $89 \cdot 5$ & $6 / 6$ & $(100)$ \\
\hline City and Hackney & 63 & 45 & $71 \cdot 4$ & 51 & $81 \cdot 0$ & $4 / 23$ & $(17 \cdot 4)$ & 45 & 26 & $57 \cdot 8$ & 38 & $84 \cdot 4$ & $7 / 8$ & $(87 \cdot 5)$ \\
\hline Enfield & 20 & 14 & $70 \cdot 0$ & 20 & 100 & $0 / 8$ & (0) & 12 & 5 & $41 \cdot 7$ & 10 & $83 \cdot 3$ & $3 / 3$ & $(100)$ \\
\hline Haringey & 33 & 10 & $30 \cdot 3^{* * *}$ & 25 & $75 \cdot 8$ & $0 / 7$ & (0) & 24 & 14 & $58 \cdot 3$ & 20 & $83 \cdot 3$ & $1 / 8$ & $(12 \cdot 5)$ \\
\hline Havering & 21 & 9 & $42 \cdot 9$ & 16 & $76 \cdot 2$ & $0 / 5$ & (0) & 11 & 10 & $90 \cdot 9$ & 11 & 100 & $0 / 3$ & (0) \\
\hline Islington & 14 & 5 & $35 \cdot 7$ & 8 & $57 \cdot 1$ & $1 / 6$ & $(16 \cdot 7)$ & 16 & 11 & $68 \cdot 8$ & 13 & $81 \cdot 3$ & $3 / 4$ & $(75 \cdot 0)$ \\
\hline Newham & 39 & 27 & $69 \cdot 2$ & 33 & $84 \cdot 6$ & $0 / 10$ & (0) & 28 & 15 & $53 \cdot 6$ & 25 & $89 \cdot 3$ & $4 / 6$ & $(66 \cdot 7)$ \\
\hline Redbridge & 28 & 14 & $50 \cdot 0$ & 23 & $82 \cdot 1$ & $1 / 14$ & $(7 \cdot 1)$ & 18 & 10 & $55 \cdot 6$ & 15 & $83 \cdot 3$ & $2 / 6$ & $(33 \cdot 3)$ \\
\hline Tower Hamlets & 13 & 6 & $46 \cdot 2$ & 8 & $61 \cdot 5$ & $2 / 3$ & $(66 \cdot 7)$ & 12 & 5 & $41 \cdot 7$ & 10 & $83 \cdot 3$ & $3 / 3$ & $(100)$ \\
\hline Waltham Forest & 26 & 21 & $80 \cdot 8^{*}$ & 22 & $84 \cdot 6$ & $0 / 11$ & (0) & 23 & 16 & $69 \cdot 6^{* *}$ & 20 & $87 \cdot 0$ & $3 / 3$ & $(100)$ \\
\hline All north east London & 291 & 172 & $59 \cdot 1$ & 236 & $81 \cdot 1$ & $9 / 99$ & $(9 \cdot 1)$ & 220 & 123 & $55 \cdot 9$ & 191 & $86 \cdot 8^{* * *}$ & $* 32 / 56$ & $(57 \cdot 1)$ \\
\hline England & 4819 & 2905 & $60 \cdot 3$ & 3831 & $79 \cdot 5$ & NA & & 3797 & 2129 & $56 \cdot 1$ & 2941 & $77 \cdot 5$ & NA & \\
\hline
\end{tabular}

+Figures obtained from DHSS, Local Health Statistics 27/1.

¥Figures taken from admission books, neonatal intensive care units at The London Hospital and University College Hospital.

NA $=$ not available.

${ }^{*} 0.01<\mathrm{P}<0.05 ; * * 0.001<\mathrm{P}<0.01 ; * * \mathbf{P}<0.001$ when the value is compared with the relevant England figures. 
Table 3 Live births $\dagger$, deaths within 24 hours $\dagger$ and 28 days $\dagger$, and admissions $\ddagger$ to neonatal intensive care for babies weighing 1001-1500 g by Health District, Greater London part of North-east Thames Health Region

\begin{tabular}{|c|c|c|c|c|c|c|c|c|c|c|c|c|c|c|}
\hline \multirow[t]{4}{*}{ Health district } & \multicolumn{5}{|c|}{$1971-73$} & \multirow{2}{*}{\multicolumn{2}{|c|}{$\begin{array}{l}1972 \\
\begin{array}{l}\text { Admitted for } \\
\text { intensive care }\end{array}\end{array}$}} & \multicolumn{5}{|c|}{$1975-77$} & \multirow{2}{*}{\multicolumn{2}{|c|}{$\begin{array}{l}1976 \\
\text { Admitted for } \\
\text { intensive care }\end{array}$}} \\
\hline & \multirow[t]{3}{*}{$\begin{array}{l}\text { Live } \\
\text { births }\end{array}$} & \multicolumn{4}{|c|}{ Deaths within } & & & \multirow[t]{3}{*}{$\begin{array}{l}\text { Live } \\
\text { births }\end{array}$} & \multicolumn{4}{|c|}{ Deaths within } & & \\
\hline & & \multicolumn{2}{|c|}{24 hours } & \multicolumn{2}{|c|}{28 days } & \multirow[b]{2}{*}{$N o$} & \multirow[b]{2}{*}{$\%$} & & \multicolumn{2}{|c|}{24 hours } & \multicolumn{2}{|c|}{28 days } & \multirow[b]{2}{*}{ No } & \multirow[b]{2}{*}{$\%$} \\
\hline & & No & $\%$ & No & $\%$ & & & & No & $\%$ & No & $\%$ & & \\
\hline Barking & 34 & 13 & $38 \cdot 2$ & 19 & $55 \cdot 9$ & $0 / 12$ & (0) & 30 & 9 & $30 \cdot 0$ & 15 & $50 \cdot 0$ & $1 / 7$ & $(14 \cdot 3)$ \\
\hline Camden & 42 & 9 & $21 \cdot 4$ & 17 & $40 \cdot 5$ & $5 / 13$ & $(38 \cdot 5)$ & 50 & 4 & $8 \cdot 0^{*}$ & 9 & $18 \cdot 0^{*}$ & $8 / 14$ & $(57 \cdot 1)$ \\
\hline City and Hackney & 63 & 14 & $22 \cdot 2$ & 26 & $41 \cdot 3$ & $6 / 23$ & $(26 \cdot 1)$ & 57 & 5 & $8 \cdot 8^{*}$ & 18 & $31 \cdot 6$ & $12 / 16$ & $(75 \cdot 0)$ \\
\hline Enfield & 50 & 13 & $26 \cdot 0$ & 20 & $40 \cdot 0$ & $1 / 18$ & $(5 \cdot 6)$ & 43 & 5 & $11 \cdot 6$ & 11 & $25 \cdot 6$ & $5 / 5$ & $(100 \cdot 0)$ \\
\hline Haringey & 75 & 12 & $16 \cdot 0^{*}$ & 22 & $29 \cdot 3^{*}$ & $0 / 17$ & (0) & 47 & 6 & $12 \cdot 8$ & 12 & $25 \cdot 5$ & $6 / 16$ & $(37 \cdot 5)$ \\
\hline Havering & 42 & 9 & $21 \cdot 4$ & 18 & $42 \cdot 9$ & $0 / 19$ & (0) & 20 & 3 & $15 \cdot 0$ & 5 & $25 \cdot 0$ & $1 / 6$ & $(16 \cdot 7)$ \\
\hline Islington & 47 & 7 & $14 \cdot 9$ & 19 & $40 \cdot 4$ & $4 / 18$ & $(22 \cdot 2)$ & 35 & 2 & $5 \cdot 7^{*}$ & 4 & $11 \cdot 4^{* *}$ & $7 / 8$ & $(87 \cdot 5)$ \\
\hline Newham & 70 & 21 & $30 \cdot 0$ & 32 & $45 \cdot 7$ & $2 / 28$ & $(7 \cdot 1)$ & 65 & 8 & $12 \cdot 3$ & 25 & $38 \cdot 5$ & $11 / 27$ & $(40 \cdot 7)$ \\
\hline Redbridge & 23 & 5 & $21 \cdot 7$ & 6 & $26 \cdot 1$ & $0 / 10$ & (0) & 27 & 3 & $11 \cdot 1$ & 5 & $18 \cdot 5$ & $6 / 11$ & $(54 \cdot 5)$ \\
\hline Tower Hamlets & 39 & 10 & $25 \cdot 6$ & 21 & $53 \cdot 8$ & $8 / 13$ & $(61 \cdot 5)$ & 43 & 0 & $0^{* * *}$ & 7 & $16 \cdot 3^{*}$ & $17 / 20$ & $(85 \cdot 0)$ \\
\hline Waltham Forest & 35 & 15 & $42 \cdot 9^{*}$ & 16 & $45 \cdot 7$ & $0 / 14$ & (0) & 48 & 7 & $14 \cdot 6$ & 21 & $43 \cdot 8$ & $5 / 13$ & $(38 \cdot 5)$ \\
\hline All north east London & 520 & 128 & $24 \cdot 6$ & 216 & $41 \cdot 5$ & $26 / 185$ & $5(14 \cdot 1)$ & 465 & 52 & $11 \cdot 2^{* * *}$ & 132 & $28 \cdot 4^{* *}$ & $79 / 143$ & $(55 \cdot 2)$ \\
\hline England & 9209 & 2515 & $27 \cdot 3$ & 3957 & $43 \cdot 0$ & NA & & 7809 & 1586 & $20 \cdot 3$ & 2711 & $34 \cdot 7$ & NA & \\
\hline
\end{tabular}

†Figures obtained from DHSS, Local Health Statistics 27/1.

†Figures taken from admissions books, neonatal intensive care units at The London Hospital and University College Hospital.

NA $=$ not available.

${ }^{*} 0.01<\mathrm{P}<0.05 ;{ }^{* *} 0.001<\mathrm{P}<0.01 ;{ }^{* * *} \mathrm{P}<0.001$ when value is compared with the relevant England figures.

and 1976 were similar (Table 4). Mortality rates for babies weighing $1000 \mathrm{~g}$ or less were similar to those for the rest of England in 1972 at 24 hours and 28 days and at 24 hours in 1976, but were significantly worse at 28 days in $1976(\mathrm{P}<0.001)$. For the larger babies (1001-1500 $\mathrm{g}$ at birth) the mortality rates in 1972

Table 4 Comparison of birthweights of babies born, weighing $1500 \mathrm{~g}$ or less, to women normally resident in the north eastern quadrant of Greater London and admitted to neonatal intensive care at The London or University College Hospitals, 1972 and 1976

\begin{tabular}{lll}
\hline $\begin{array}{l}\text { Birthweights } \\
(g)\end{array}$ & $\begin{array}{l}\text { Number of babies admitted to neonatal } \\
\text { intensive care }\end{array}$ \\
\cline { 2 - 3 } & $1972(n=35)$ & $1976(n=111)$ \\
\hline$<801$ & 3 & 14 \\
$801-900$ & 2 & 9 \\
$901-1000$ & 4 & 9 \\
$1001-1100$ & 4 & 21 \\
$1101-1200$ & 6 & 17 \\
$1201-1300$ & 1 & 11 \\
$1301-1400$ & 3 & 14 \\
$1401-1500$ & 12 & 16 \\
\hline
\end{tabular}

$\chi^{2}=3 \cdot 19,3$ df $P>0 \cdot 2$ Because of small numbers $\chi^{2}$ was used for the following birth groups: <901,901-1100,1101-1300, and 1301-1500 g. Median birthweight: $1972: 1200 \mathrm{~g}$. 1976: $1130 \mathrm{~g}$.

Median birthweight of babies weighing $1000 \mathrm{~g}$ and less: 1972: $900 \mathrm{~g}$. 1976: $840 \mathrm{~g}$.

Median birthweight of babies weighing 1001-1500 g. 1972: $1393.5 \mathrm{~g}$ 1976: $1239 \mathrm{~g}$.

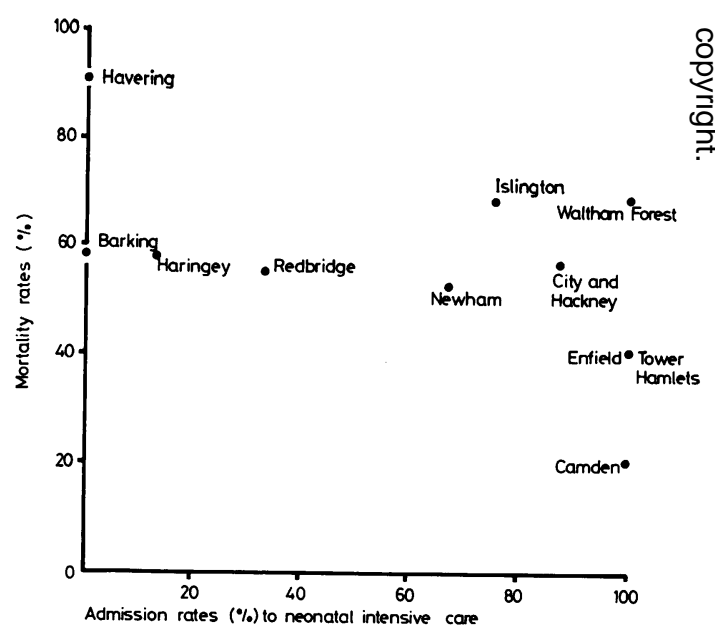

Fig. 2 Death rates at 24 hours compared with admission rates to neonatal intensive care (1976) for babies born weighing $1000 \mathrm{~g}$ and less (1975-77).

were also similar to those for the rest of England at both ages. In 1976 the survival rates were significantly better at 24 hours $(P<0.001)$ and at 28 days $(0.01>P>0.001)$ (Tables 2 and 3$)$. The two districts in which the neonatal intensive care units are located have significantly better survival rates at both 24 hours and 28 days for the larger babies. 
There was no correlation in 1972 between admission rates to neonatal intensive care and survival at 24 hours and 28 days for either birthweight group. This was the case also in 1976 for the smaller babies (Figs 2 and 3) but for babies weighing 1001 to $1500 \mathrm{~g}$ there was a correlation of $r=-0.73$ at 24 hours, and $r=-0.60$ at 28 days (Figs 4 and 5); the correlation was statistically significant $(0.02>P>0.01,9 \mathrm{df})$

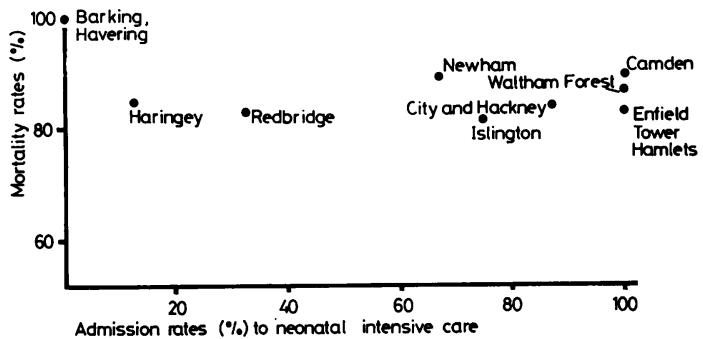

Fig. 3 Death rates at 28 days compared with admission rates to neonatal intensive care (1976) for babies born weighing $1000 \mathrm{~g}$ and less (1975-77).

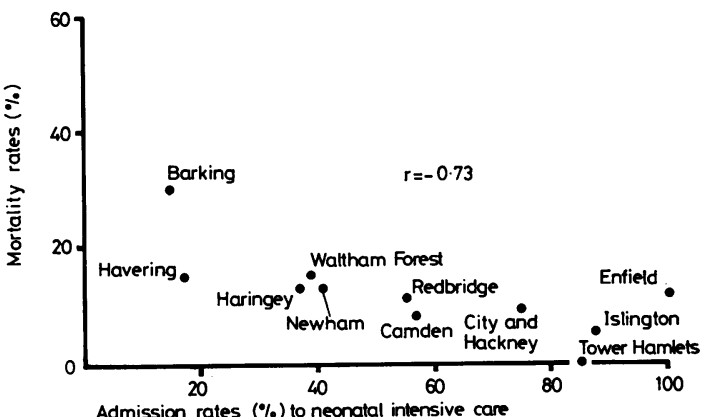

Fig. 4 Death rates at 24 hours compared with admission rates to neonatal intensive care (1976) for babies born weighing 1001-1500 g (1975-77).

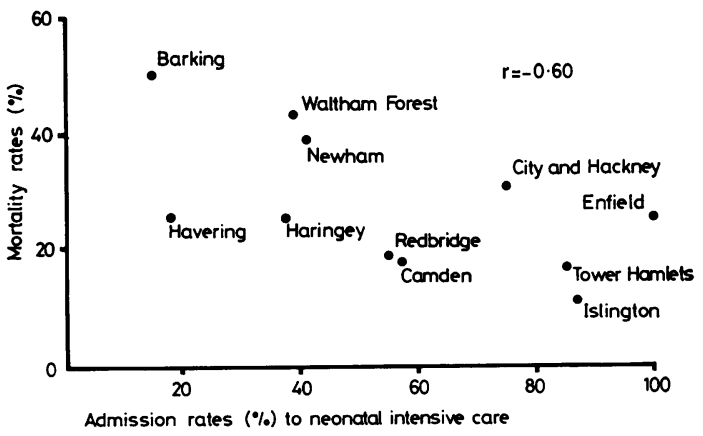

Fig. 5 Death rates at 28 days compared with admission rates to neonatal intensive care (1976) for babies born weighing 1001-1500 $\mathrm{g}$ (1975-77). for survival at 24 hours but not at 28 days $(0 \cdot 10>P>0 \cdot 05,9 \mathrm{df})$.

\section{Discussion}

There have been notable developments in neonatal care during the last decade, ${ }^{14}$ and studies have shown that special care baby units are not equipped to provide the necessary highly specialised care..$^{15} 16$ The impact of neonatal care on reducing community mortality rates of very small infants has been questioned. ${ }^{1-35} 56$ The present study however relates local survival rates to different levels of admission to neonatal intensive care. Higher survival rates for babies born in north-eastern London, weighing between 1001 and $1500 \mathrm{~g}$ at birth in 1976 were significantly associated with higher admission rates to neonatal intensive care. No correlation was shown between mortality and admission rates to intensive care for babies born weighing between 1001 and $1500 \mathrm{~g}$ in 1972 , or for babies weighing $1000 \mathrm{~g}$ or less in 1972 or 1976.

This investigation has not been able to establish the importance of the speed with which admission is made, and the care available during transfer to neonatal intensive care because such information was not available for both units. It has been shown elsewhere that small and sick babies can be safely transported in specially equipped ambulances for fairly long distances, ${ }^{17}$ although outcome is better if transfer occurs in utero. ${ }^{18}$

There are large discrepancies in admission rates to neonatal intensive care of small babies. If greater benefit is to be attained, as has been advocated, ${ }^{19}$ it is important that policies of care should be agreed. As such services are truly regional, it is desirable that there should be regular surveillance and assessment to ensure that very small babies are speedily transferred to suitable units, and their outcome should be monitored.

We thank the staff of the neonatal intensive care units and the paediatricians in charge of the special care baby units in the North East Thames Health Region for co-operation, Professor J N Morris for constructive criticism, and Miss Jane Cooper for statistical advice.

The North East Thames Regional Health Authority provided financial support.

\section{References}

1 Gordon R R. Neonatal and 'perinatal' mortality rates by birth weight. $\mathrm{Br}$ Med J 1977; ii: 1202-4.

2 Jones R A K, Cummins M, Davies P A. Infants of very low birthweight: a 15 year analysis. Lancet 1979; i: 1332-5. 
${ }^{3}$ Gordon R R. Letter: Intensive care and the very low birthweight infant. Lancet 1979; ii: 36.

4 Dunn P M, Speidel B D, Fleming P J. Intensive care and the very low birthweight infant. Lancet 1979; ii: 254-5.

5 Gordon R R. Letter: Neonatal superintensive care. Br Med J 1979; ii: 443.

- Anonymous. Obstetrics: intensive care risk. The Times $1979 ; 16$ November, page 14, column 2.

7 Roberton N R C. Letter: Intensive care and the very low birthweight infant. Lancet 1979; ii: 362.

8 Smith M L, Spencer S A, Hull D. Mode of delivery and survival in babies weighing less than $2000 \mathrm{~g}$ at birth. Br Med J 1980; 281 : 1118-9.

- Reynolds E O R, Stewart A L. Letter: Intensive care and the very low birthweight infant. Lancet 1979; ii: 254.

10 Reynolds E O R, Stewart A L. Letter: Intensive care risk. The Times 1980; 2 January, page 9, column 5.

11 Macfarlane A, Chalmers I, Adelstein A M. The role of standardization in the interpretation of perinatal mortality rates. Health Trends 1980; 12: 45-50.

12 Chiswick M L, Davies P, Bate R, Dryburgh E, GordonNesbitt $D$. Regional organisation of neonatal intensive care in the north-west. Br Med J 1979; ii : 247-50.

13 Simpson H, Walker G. Estimating the cots required for neonatal intensive care. Arch Dis Child 1981; 56: 90-3.

14 Fitzhardinge P M, Kalman E, Ashby S, Pape K E. Present status of the infant of very low birthweight treated in a referral neonatal intensive care unit in 1974. In:
Elliott K, O'Connor M, eds. Major mental handicap: methods and costs of prevention. Ciba Foundation Symposium 59 (new series). Amsterdam: Elsevier, 1978: 139-50.

15 Alberman E, Collingwood J, Pharoah P O D, Vaizey J, Oppé T E. Arrangements for special and intensive care of the newborn. Br Med J 1977; ii : 1045-7.

16 Vaizey J, Oppé T E. Study of special-care baby services in North-west Thames region. $\mathrm{Br} \mathrm{Med} J 1979$; i: 583-5.

17 Blake A M, McIntosh N, Reynolds E O R, St Andrew D. Transport of newborn infants for intensive care. $\mathrm{Br}$ Med $\mathrm{J}$ 1975 ; iv: $13-7$.

18 Blake A M, Pollitzer M J, Reynolds E O R. Referral of mothers and infants for intensive care. $B r$ Med $J$ 1979; ii: 414-6.

19 House of Commons. Second Report from the Social Services Committee: session 1979-80. Perinatal and neonatal mortality. London: HMSO, 1980: paragraphs 99-123.

Correspondence to $\operatorname{Dr}$ G J A Walker, Ross Institute of Tropical Hygiene, London School of Hygiene and Tropical Medicine, Keppel Street, London WC1E 7HT.

Received 20 July 1981 